\title{
Does heroin addiction makes temperamental changes?
}

\author{
Hristina Martinova ${ }^{1 *}$, Tony Donchev $^{3}$, Vihra Milanova ${ }^{2}$, Hagop Akiskal ${ }^{4}$ \\ From $1^{\text {st }}$ International Congress on Neurobiology and Clinical Psychopharmacology and European \\ Psychiatric Association Conference on Treatment Guidance \\ Thessaloniki, Greece. 19-22 November 2009
}

\section{Background}

Investigation of specific personality traits is still in focus of modern psychiatry for years. The target usually pursues identification of those personality traits, described as a predisposition of addiction. But the question of fowl and egg is still open: are these traits are predispositions or they are consequences of Heroin personality change. Based on "mathematical" admission that temperamental traits describe an unchangeable basic concept we verify our hypothesis over addicted population.

\section{Materials and methods}

Heroin addicted and healthy group was assessed with TEMPS-A questionnaire to evaluate statistical significant differences between groups. 50 Heroin addicted and 50 healthy controls were engaged in this research. The target group includes in-patients hospitalized for heroin dependency treatment. Patients with concomitant psychiatric or organic mental disorder were excluded from enrolment. Healthy controls were randomly selected.

\section{Results}

The results demonstrate statistically significant differences between groups by "depressive" and "irritable" temperaments.

\section{Conclusions}

This study doesn't have ambition to give the right answer for the big question about predispositions or consequences, but it may be gives idea for the right questions.

\section{Author details}

${ }^{1}$ Medical University, Sofia, Bulgaria. ${ }^{2}$ Military Medical Academy, Clinic of Psychiatry, Sofia, Bulgaria. ${ }^{3}$ Medical University - Sofia, Department of Psychiatry, Sofia, Bulgaria. International Mood Center, The San Diego Veterans Administration Medical Center, University of California at San Diego, California, USA.

Published: 22 April 2010

\section{References}

1. Chang HL, Chen SH, Huang C: Temperament of Juvenile Delinquents with History of Substance Abuse. Chang Gung Med J 2007, 30(1).

2. Craig RJ: The Personality Structure of Heroin Addicts; NIDA, "Neurobiology of Behavioral Control in Drug Abuse". Research Monograph, Series 74 .

3. Henderson MJ, Galen LW, DeLuca JW: Temperament Style and Substance abuse Characteristics. Journal of Substance Abuse, Springer Netherland 1998, 19(2).

4. Pompili M, Innamorati M, Lester D, Akiskal HS, Rihmer Z, Del Casale A, Amore M, Girardi P, Tatarelli R: Substance Abuse, Temperament and Suicide Risk: Evidence from a Case-Control Study. Journal of Addictive Diseases 2009, 28(1)

\section{doi:10.1186/1744-859X-9-S1-S141}

Cite this article as: Martinova et al:: Does heroin addiction makes temperamental changes?. Annals of General Psychiatry 2010 9(Suppl 1): S141.
Submit your next manuscript to BioMed Central and take full advantage of:

- Convenient online submission

- Thorough peer review

- No space constraints or color figure charges

- Immediate publication on acceptance

- Inclusion in PubMed, CAS, Scopus and Google Scholar

- Research which is freely available for redistribution
C Biomed Central 